\title{
Phenotypic stability of strawberry cultivars assessed in three environments
}

A. Gabriel ${ }^{1}$, J.T.V. Resende ${ }^{1}$, A.R. Zeist ${ }^{2}$, L.V. Resende ${ }^{2}$, N.C.V. Resende ${ }^{2}$, A.G. Galvão ${ }^{2}$, R.A. Zeist ${ }^{1}$, R.B. de Lima Filho ${ }^{1}$, J.V.W. Corrêa ${ }^{1}$ and C.K. Camargo ${ }^{1}$

${ }^{1}$ Universidade Estadual do Centro-Oeste, Guarapuava - PR, Brasil

${ }^{2}$ Universidade Federal de Lavras, Lavras - MG, Brasil

Corresponding author: A. Gabriel

E-mail: andreagrounicentro@gmail.com

Genet. Mol. Res. 17 (3): gmr18041

Received May 29, 2018

Accepted July 26, 2018

Published August 27, 2018

DOI http://dx.doi.org/10.4238/gmr18041

ABSTRACT. We examined the agronomic performance and stability of strawberry cultivars in three environments, using the Annicchiarico and AMMI methods. Thirteen strawberry cultivars were evaluated (Aromas, Oso Grande, Dover, Sweet Charlie, Tudla, Festival, Camarosa, Monterey, Palomar, Portola, Camino Real, San Andreas and Albion), in the towns of Lavras-MG, Guarapuava-PR and Uberlândia-MG. The experimental design was blocks with randomly distributed treatments, with four replications and 18 plants per experimental unit. The total number of fruits (TNF) plant ${ }^{-1}$, total mass of fruits (TMF) g plant ${ }^{-1}$, number of commercial fruits (NCF) plant $^{-1}$ and mass of commercial fruits (MCF) $g$ plant ${ }^{-1}$ were evaluated. Variance analysis detected a significant effect for cultivar, environment, and cultivar $\mathrm{x}$ environment interaction for all the characteristics. The agronomic performance of the Dover cultivar stood out for TNF, TMF and NCF, while the Camarosa cultivar stood out for MCF. When we examined phenotypic stability in terms of yield in different cultivation environments, the Albion cultivar stood out for TMF, and Monterey and San Andreas for NFC.

Key words: Fragaria $\mathrm{x}$ ananassa Duch.; AMMI; Annicchiarico; Fruit production 


\section{INTRODUCTION}

Strawberry crops (Fragaria $\mathrm{x}$ ananassa Duch) have a wide geographic distribution (Morales et al. 2012). Most of the genotypes of commercially grown strawberries in Brazil originate from genetic improvement programs in the United States (Galvão et al. 2017), and they are not well adapted to the diverse edaphoclimatic conditions existing in Brazil.

The interaction between phenotype and environment is marked in strawberry crops (Pereira et al. 2013; Rosa et al. 2013; Costa et al. 2015; Costa et al. 2016) and restricts the selection and the recommendation of the same cultivar in several environments. Cultivars that adapt to a broader range of environments are common; while others have a limited adaptation to the places they are grown. Some statistical methods help understand the interaction (Ramos et al. 2011).

In order to evaluate stability, the Annicchiarico (1992) and AMMI (Zobel et al. 1988), methodologies have been employed in an attempt to find the most stable strawberry cultivars in the evaluation environments. The AMMI analysis allows the best details of the level of the sum of squares of the interaction in a unique mathematical and statistical model (García-Peña and Dias, 2009). On the other hand, the Annicchiarico method (1992) is based on variance analysis, where the general confidence indexes $\left(\omega_{i}\right)$ are estimated, for favorable and unfavorable environments (Cruz et al. 2014). Thus, the higher the index value $\left(\omega_{i}\right)$, the greater is the chance of success and confidence in the choice of the cultivar with the greatest stability (Cruz et al. 2014).

Evaluation of stability by using the Annicchiarico method has been reported by several authors and in several species, such as maize (Schmildt et al. 2011; Possatto Júnior et al. 2017a; Silva et al. 2017), canola (Lima et al. 2017), and soybean (Barros et al. 2012). Recommendation of phenotypes based on an analysis of stability by Annicchiarico is reliable and has results that are similar to those of other methods (Schmildt et al. 2011; Barros et al. 2012). On the other hand, the AMMI method has been used on onion (Oliveira et al. 2016) and manioc (Morais et al. 2017) populations. Use of the two methodologies (AMMI and Annicchiarico) is reported for wheat (Possatto Júnior et al. 2017b; Bornhofen et al. 2017).

Several studies of adaptability and stability in vegetable crops have been carried out in recent years in Brazil, such as in pumpkin (Santos et al. 2015), pepper (Pimenta et al. 2016), carrot (Carvalho et al. 2017) and onion (Oliveira et al. 2016). However, for strawberries, studies of agronomic performance and phenotypic stability of cultivars using the Annicchiarico and AMMI methods are rare, having mainly been applied to recentlylaunched varieties and varieties considered to have a neutral photoperiod in contrasting environments.

We evaluated the phenotypic stability of 13 strawberry cultivars in the municipalities of Lavras-MG, Guarapuava-PR and Uberlândia-MG, employing the Annicchiarico and AMMI methods.

\section{MATERIAL AND METHODS}

The experiments were implemented during the agricultural year 2013 in Guarapuava, Paraná (PR) state, and in 2014 in Lavras, Minas Gerais (MG) state, and Uberlândia, MG. In Guarapuava, PR, the experiment was conducted at the Agricultural 
Research Center of the Department of Agronomy of the Central-West State University, CEDETEG campus, at an altitude of 1,100 meters. The soil is Dusky Dystroferric Latosol (Embrapa, 2013). The climate, according to the Köppen classification, is humid mesothermic subtropical, with no defined dry season, hot summers and moderate winters. In Lavras, MG, the experiment was conducted at the Olericulture Sector of the Department of Agriculture of the Federal University of Lavras, at an altitude of 918 meters in a Red Dystroferric Latosol (Embrapa, 2013). The climate, according to the Köppen classification, is Cwa, rainy temperate (mesothermic), with a dry winter and a rainy summer. In Uberlândia, MG, the experiment was conducted at the Federal University of Uberlândia, UMUARAMA campus, at an altitude of $843 \mathrm{~m}$ and a Red Latosol soil (Embrapa, 2013). The predominant climate of the region is Cwa, i.e., subtropical with dry winters and hot summers, according to the Köppen classification.

The experiments were initiated during the first week of May, 2013 in Guarapuava, and the same week in 2014 in Lavras and Uberlândia. An experimental design of blocks with randomly distributed treatments was used, evaluating 13 cultivars (Aromas, Oso Grande, Dover, Sweet Charlie, Tudla, Festival, Camarosa, Monterey, Palomar, Portola, Camino Real, San Andreas and Albion), with four replicates, each consisting of 18 plants.

The cultivars were carried out in a system of tunnels, $1.0 \mathrm{~m}$ high in the central part, covered with a low density 100 micron polyethylene film, and with beds $1.0 \mathrm{~m}$ wide by 0.25 $\mathrm{m}$ high, coated with a black polyethylene film 30 microns thick. The cultivars were planted in quincunx, with $0.3 \mathrm{~m} \times 0.3 \mathrm{~m}$ spacing. The lateral parts of the tunnels were raised during the day for better ventilation and to facilitate the action of pollinator agents, and closed during the night to avoid leaf wetting.

Throughout the cycle, micro-drippers were used for irrigation, with fertirrigation in the morning, employing recommendations by Trani (2011), with some adaptations, according to the developmental stage of the crop. The plants were sprayed fortnightly, with calcium (10\%) and boron $(0.05 \%)$, according to technical recommendations. Phytosanitary control was carried out with preventive sprayings of commercial products that contained thiamethoxam $\left(\right.$ Actara $\left.^{\circledR}\right)$ and azoxystrobin + diphenoconazole (Amistar Top $\left.{ }^{\circledR}\right)$, according to technical recommendations.

Fruit harvest was conducted by collecting those that were in the ripening stage with $2 / 3$ red color. Harvests were evaluated with regard to the total number of fruits (TNF, plant ${ }^{1}$ ), determined by the sum of the total number of fruits collected on the different dates when the harvests were carried out; the number of commercial fruits $\left(\mathrm{NCF}, \mathrm{g} \mathrm{plant}^{-1}\right)$, determined by sum of the number of fruits classified within commercial standards; total mass of fruits (TMF, g plant ${ }^{-1}$ ) determined by the weighing of the total accumulated production of fruits; and mass of commercial fruits (MCF, g plant ${ }^{-1}$ ), determined by weighing the accumulated production of fruits classified to be within commercial standards.

The results were subjected to the Bartlett and Shapiro-Wilk tests, fulfilling the assumptions of homogeneity of the variances and normality of errors; the analysis of individual and joint variance was performed considering the fixed model for genotypes and environments. The means were grouped by the Scott Knott test at 5\% probability. An analysis of phenotypic stability was also carried out by the Annicchiarico method (1992), with the aid of the statistical software GENES (Cruz, 2013) and AMMI (Zobel et al. 1988) in the Stability software (Ferreira, 2000). 


\section{RESULTS AND DISCUSSION}

Accumulated rainfall during the period of the conduction of the experiments was distinct among the environments, with 1205, 395 and $519 \mathrm{~mm}$ for Guarapuava, Lavras and Uberlândia, respectively (Figure 1). Too much rain, such as in Guarapuava, can contribute to a reduction of the action of pollinator agents. In Guarapuava, severe frosts that harmed plant development were also observed; on July 23, 2013, there was snow during the flowering stage and fruit production, which resulted in reduced pollination and abortion of flowers, and a reduction in fruit production.

In the analysis of joint variance there was a significant effect for cultivar, environment and cultivar $x$ environment interactions with regard to NTF, TMF, NCF and MCF (Table 1), demonstrating genetic variability among the cultivars, and inconsistency in their behavior in response to environmental oscillations. Other studies also found interactions between strawberry cultivars and crop environments (Pereira et al. 2013; Rosa et al. 2013; Costa et al. 2015; Costa et al. 2016). This shows the importance of studies on stability of strawberry cultivars.
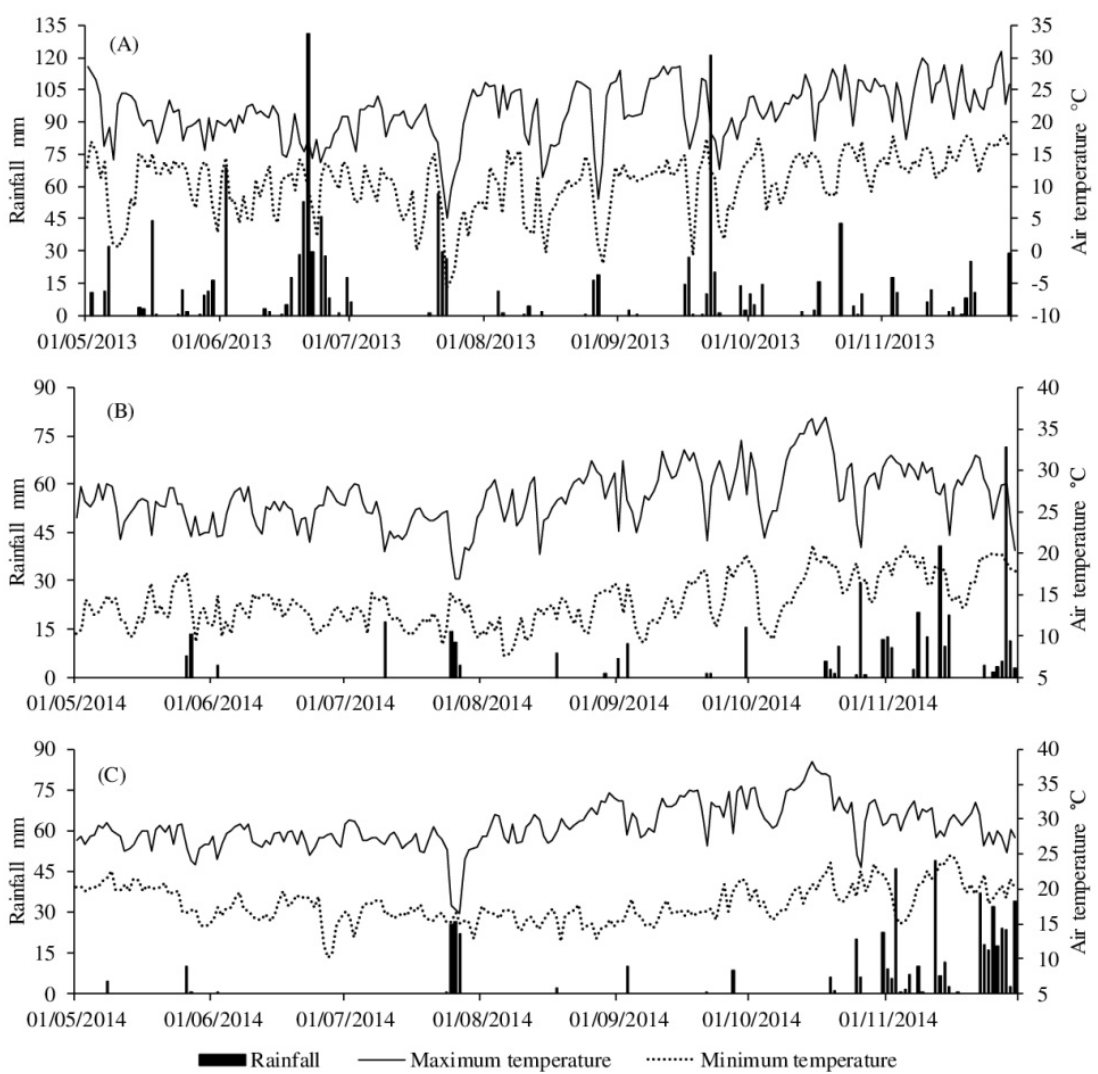

Figure 1. Values of the climatic variables, rainfall $(\mathrm{mm})$, maximum and minimum temperature $\left({ }^{\circ} \mathrm{C}\right)$ in Guarapuava-PR (A), Lavras-MG (B) and Uberlândia-MG (C) during the planting trials. 
Table 1. Summary of the analysis of joint variance for the characteristics: fruit number (TNF, plant ${ }^{-1}$ ), total mass of fruits (TMF, g plant $\left.{ }^{-1}\right)$, number of commercial grade fruits $\left(\mathrm{NCF}\right.$, plant $\left.{ }^{-1}\right)$, mass of commercial fruits $(\mathrm{MCF}, \mathrm{g}$ plant $^{-1}$ ), and analysis of stability (AMMI), with percentage of explanation of variance, for 13 strawberry cultivars assessed in the environments of Lavras-MG, Guarapuava-PR and Uberlândia-MG.

\begin{tabular}{lccccc}
\hline & & \multicolumn{3}{c}{ Mean square } \\
\cline { 3 - 6 } Source of variation & DF & TNF & TMF $(\mathrm{g})$ & NCF & MCF $(\mathrm{g})$ \\
\hline Cultivar (C) & 12 & $9602.44^{* *}$ & $589807.02^{* *}$ & $1074.19^{* *}$ & $318414.63^{* *}$ \\
Environment (A) & 2 & $2657.62^{*}$ & $1268166.47^{* *}$ & $7304.80^{* *}$ & $1701710.44^{* *}$ \\
C x E & 24 & $1714.14^{* *}$ & $252764.22^{* *}$ & $659.77^{* *}$ & $231317.03^{* *}$ \\
PCAI 1 & 13 & 2538.42 & 429528.75 & 1048.97 & 401173.82 \\
Residual & 114 & 668.00 & 52492.00 & 145.00 & 44321.00 \\
\hline Explanation (\%) & & 80.21 & 92.04 & 86.11 & 93.94 \\
\hline Mean & & 96.26 & 899.50 & 52.38 & 702.88 \\
\hline CV $(\%)$ & 26.86 & 24.25 & 21.94 & 38.87 \\
\hline
\end{tabular}

**,*Significant at the levels of $(\mathrm{P}<0.01)$ and $(\mathrm{P}<0.05)$ probability by the $\mathrm{F}$ test, respectively.

When comparing the mean in each environment, Uberlândia was higher for the TNF, NCF and MCF characteristics, Uberlândia and Lavras were higher for TMF. On the other hand, Guarapuava had the lowest performance for TMF and MCF (Table 2). Distinct results among the environments may be due to the considerable geographical distance between the sites, and the influence of the environmental elements on the phenotypic expression of the cultivars, especially temperature, photo period, rainfall and fertility of the soil.

In Uberlândia, the mean TNF (104.05) was higher than in Lavras (90.00) and Guarapuava (94.71) (Table 2), showing accordance with the analysis of adaptability and stability by the Annicchiarico method (1992), in which Uberlândia was rated as a favorable environment with an environmental index of 7.79 (Table 3).

In the analysis of TNF, taking into account the general environment, cultivars Dover, Camarosa and San Andreas obtained indexes of confidence $\left(\omega_{i}\right)$ above $100 \%$, indicating that these strawberry cultivars maintained above average productivity, even when subjected to different soil and climate conditions. However, when considering only unfavorable environments, cultivars Dover, Festival, Camarosa and Camino Real stood out, with indexes of confidence $\left(\omega_{\mathrm{i}}\right)$ above $100 \%$ (Table 2 ). These results show that these cultivars maintained good levels of productivity, even in environments that did not have favorable conditions.

The Dover cultivar stood out for TNF in comparison with the other environments of Guarapuava and Uberlândia, while it, together with Camarosa, was ranked in the first group of cultivars for the Lavras environment (Table 2). These results were possibly the ones that contributed for these cultivars to be considered suitable for production, considering both the general environment and the unfavorable ones for these characteristics. The mean TMF for the environments Uberlândia (1018.92) and Lavras (956.80) was higher than that of Guarapuava (722.88, Table 2), being in accordance with the Annicchiarico environmental classification, which considered the two environments from Minas Gerais State favorable (Lavras 57.30 and Uberlândia 119.41) (Table 3). For this characteristic in Lavras, cultivars Oso Grande (1081.75 g), Dover (1213.25 g), Camarosa (1251.00 g), Camino Real (1122.75 g) and Albion (1156.88) stood out; in Guarapuava, Dover (1343.43); and in Uberlândia, Oso Grande (1739.50) and Camarosa (1781.50). As for phenotypic stability, the ones that stood out were cultivars Dover, Camarosa and Albion, when considering the general environment, and Oso Grande, Camarosa and Albion, when considering a favorable environment (Table 2). 
Table 2. Number of fruits (TNF plant $\left.{ }^{-1}\right)$ and total mass of fruits (TMF g plant $\left.{ }^{-1}\right)$, number $\left(\mathrm{NCF}_{\text {plant }}{ }^{-1}\right)$ and mass of commercial fruits (MCF g plant ${ }^{-1}$ ) and parameters of stability - Annicchiarico of strawberry cultivars evaluated in Lavras-MG, Guarapuava-PR and Uberlândia-MG.

\begin{tabular}{|c|c|c|c|c|c|c|c|c|c|c|c|c|c|}
\hline \multirow[b]{2}{*}{ Cultivar } & \multicolumn{11}{|c|}{ TNF (plant ${ }^{-1}$ ) } & \multirow{3}{*}{$\begin{array}{c}\begin{array}{c}\left(\omega_{\mathrm{i}}\right) \text { General } \\
\text { environment }\end{array} \\
65.39\end{array}$} & \multirow{2}{*}{$\begin{array}{c}\left(\omega_{\mathrm{i}}\right) \text { Unfavorable } \\
\text { environment }\end{array}$} \\
\hline & \multicolumn{3}{|l|}{ Lavras-MG } & \multicolumn{3}{|c|}{ Guarapuava-PR } & \multicolumn{3}{|c|}{ Uberlândia-PR } & \multicolumn{2}{|l|}{ Mean } & & \\
\hline Aromas & 76.00 & $\mathrm{~b}$ & A & 49.675 & $\mathrm{c}$ & A & 75.50 & $\mathrm{~b}$ & A & 67.05 & $\mathrm{c}$ & & 62.25 \\
\hline Oso Grande & 77.37 & $\mathrm{~b}$ & B & 52.32 & $\mathrm{c}$ & B & 108.25 & b & A & 79.31 & $\mathrm{c}$ & 75.00 & 64.66 \\
\hline Dover & 158.12 & $\mathrm{a}$ & B & 219.67 & $\mathrm{a}$ & A & 170.75 & a & B & 182.84 & $\mathrm{a}$ & 180.64 & 192.92 \\
\hline Sweet Charlie & 91.37 & $\mathrm{~b}$ & A & 53.32 & $\mathrm{c}$ & B & 95.50 & b & A & 80.06 & $\mathrm{c}$ & 76.69 & 70.16 \\
\hline Tudla & 70.62 & $\mathrm{~b}$ & B & 58.67 & $\mathrm{c}$ & B & 113.25 & b & A & 80.84 & $\mathrm{c}$ & 76.57 & 67.01 \\
\hline Festival & 79.87 & $\mathrm{~b}$ & B & 129.00 & $\mathrm{~b}$ & A & 76.00 & b & B & 94.95 & $\mathrm{~b}$ & 90.33 & 103.29 \\
\hline Camarosa & 130.00 & $\mathrm{a}$ & A & 99.32 & $\mathrm{~b}$ & A & 105.25 & b & A & 111.52 & b & 110.25 & 116.99 \\
\hline Monterey & 77.37 & $\mathrm{~b}$ & A & 95.00 & $\mathrm{~b}$ & A & 101.75 & $\mathrm{~b}$ & A & 91.37 & $\mathrm{~b}$ & 92.58 & 90.35 \\
\hline Palomar & 75.50 & $\mathrm{~b}$ & A & 94.32 & $\mathrm{~b}$ & A & 92.50 & b & A & 87.44 & $\mathrm{c}$ & 88.59 & 88.69 \\
\hline Portola & 77.12 & b & A & 83.67 & $\mathrm{~b}$ & A & 97.50 & b & A & 86.09 & $\mathrm{c}$ & 88.12 & 86.49 \\
\hline Camino Real & 86.00 & b & A & 112.00 & $\mathrm{~b}$ & A & 84.00 & b & A & 94.00 & b & 93.00 & 102.50 \\
\hline San Andreas & 80.75 & $\mathrm{~b}$ & A & 101.00 & $\mathrm{~b}$ & A & 120.25 & b & A & 100.66 & $\mathrm{~b}$ & 100.37 & 94.90 \\
\hline Albion & 90.00 & $\mathrm{~b}$ & $\mathrm{~A}$ & 83.32 & $\mathrm{~b}$ & A & 112.25 & $\mathrm{~b}$ & $\mathrm{~A}$ & 95.19 & $\mathrm{~b}$ & 95.87 & 91.65 \\
\hline \multirow[t]{2}{*}{ Mean } & 90.00 & & $\mathrm{~B}$ & 94.71 & & $\mathrm{~B}$ & 104.05 & & $\mathrm{~A}$ & & & & \\
\hline & \multicolumn{11}{|c|}{ TMF $\left(\right.$ g plant $\left.^{-1}\right)$} & $\left(\omega_{\mathrm{i}}\right)$ General & $\left(\omega_{\mathrm{i}}\right)$ Favorable \\
\hline Cultivar & Lavras-MG & & & Guarapuava- & & & Uberlândia-M & & & Mean & & environment & environment \\
\hline Aromas & 865.00 & $\mathrm{~b}$ & A & 354.00 & $\mathrm{c}$ & B & 766.00 & $\mathrm{~d}$ & A & 661.66 & $\mathrm{c}$ & 65.79 & 79.85 \\
\hline Oso Grande & 1081.75 & $\mathrm{a}$ & B & 437.32 & $\mathrm{c}$ & $\mathrm{C}$ & 1739.50 & a & A & 1086.18 & $\mathrm{~b}$ & 99.69 & 130.74 \\
\hline Dover & 1213.25 & $\mathrm{a}$ & A & 1343.43 & $\mathrm{a}$ & A & 1451.50 & b & A & 1336.05 & $\mathrm{a}$ & 143.34 & 131.60 \\
\hline Sweet Charlie & 807.38 & b & A & 366.00 & $\mathrm{c}$ & B & 1040.50 & $\mathrm{c}$ & A & 737.95 & $\mathrm{c}$ & 71.90 & 89.82 \\
\hline Tudla & 763.25 & $\mathrm{~b}$ & A & 451.34 & $\mathrm{c}$ & B & 920.75 & $\mathrm{c}$ & A & 711.78 & $\mathrm{c}$ & 73.67 & 83.02 \\
\hline Festival & 887.75 & b & A & 904.00 & $\mathrm{~b}$ & A & 678.25 & d & A & 823.33 & $\mathrm{c}$ & 86.79 & 74.61 \\
\hline Camarosa & 1251.00 & $\mathrm{a}$ & B & 773.33 & $\mathrm{~b}$ & $\mathrm{C}$ & 1781.50 & a & A & 1268.61 & $\mathrm{a}$ & 128.11 & 144.27 \\
\hline Monterey & 757.13 & $\mathrm{~b}$ & A & 777.67 & $\mathrm{~b}$ & A & 756.50 & d & A & 763.76 & $\mathrm{c}$ & 82.07 & 75.74 \\
\hline Palomar & 851.75 & b & A & 763.67 & $\mathrm{~b}$ & A & 652.00 & d & A & 755.80 & $\mathrm{c}$ & 80.49 & 71.67 \\
\hline Portola & 766.38 & $\mathrm{~b}$ & A & 561.99 & $\mathrm{c}$ & A & 795.75 & d & A & 708.03 & $\mathrm{c}$ & 78.30 & 78.71 \\
\hline Camino Real & 1122.75 & $\mathrm{a}$ & A & 1012.67 & $\mathrm{~b}$ & A & 643.00 & d & B & 926.13 & $\mathrm{c}$ & 96.04 & 79.74 \\
\hline San Andreas & 914.25 & b & A & 768.08 & $\mathrm{~b}$ & A & 879.00 & $\mathrm{c}$ & A & 853.77 & $\mathrm{c}$ & 93.29 & 89.11 \\
\hline Albion & 1156.88 & $\mathrm{a}$ & A & 882.66 & $\mathrm{~b}$ & A & 1141.75 & $\mathrm{c}$ & A & 1060.42 & b & 116.86 & 114.77 \\
\hline Mean & 956.80 & & $\mathrm{~A}$ & 722.88 & & B & 1018.92 & & $\mathrm{~A}$ & & & & \\
\hline & & & & & $\overline{\mathrm{NCF}}$ & (plar & & & & & & $\left(\omega_{i}\right)$ General & $\left(\omega_{\mathrm{i}}\right)$ Unfavorable \\
\hline Cultivar & Lavras-MG & & & Guarapuava- & & & Uberlândia-M & & & Mean & & environment & environment \\
\hline Aromas & 43.12 & $\mathrm{~b}$ & A & 13.67 & $\mathrm{~d}$ & B & 50.50 & $\mathrm{~b}$ & A & 35.76 & $\mathrm{c}$ & 57.72 & 49.53 \\
\hline Oso Grande & 39.87 & $\mathrm{~b}$ & B & 16.32 & $\mathrm{~d}$ & $\mathrm{C}$ & 72.00 & a & A & 42.73 & $\mathrm{c}$ & 66.87 & 51.61 \\
\hline Dover & 58.75 & $\mathrm{a}$ & B & 47.67 & $\mathrm{~b}$ & B & 89.25 & a & A & 65.22 & $\mathrm{a}$ & 119.02 & 113.38 \\
\hline Sweet Charlie & 34.75 & b & B & 20.67 & d & B & 69.00 & a & A & 41.47 & $\mathrm{c}$ & 67.17 & 55.17 \\
\hline Tudla & 33.75 & $\mathrm{~b}$ & B & 33.57 & $\mathrm{c}$ & B & 77.00 & a & A & 48.11 & $\mathrm{~b}$ & 81.38 & 72.86 \\
\hline Festival & 37.10 & b & A & 44.00 & $\mathrm{~b}$ & A & 54.50 & b & A & 45.20 & b & 83.91 & 85.05 \\
\hline Camarosa & 58.37 & a & B & 37.00 & $\mathrm{c}$ & $\mathrm{C}$ & 79.50 & a & A & 58.29 & $\mathrm{a}$ & 103.44 & 96.26 \\
\hline Monterey & 48.75 & $\mathrm{a}$ & B & 59.67 & $\mathrm{a}$ & B & 71.00 & $\mathrm{a}$ & A & 59.80 & $\mathrm{a}$ & 110.65 & 113.06 \\
\hline Palomar & 42.25 & b & A & 57.00 & $\mathrm{a}$ & A & 55.25 & b & A & 51.50 & b & 94.08 & 101.68 \\
\hline Portola & 46.50 & b & A & 49.67 & $\mathrm{~b}$ & A & 56.50 & b & A & 50.88 & $\mathrm{~b}$ & 95.26 & 102.78 \\
\hline Camino Real & 54.50 & $\mathrm{a}$ & B & 66.67 & $\mathrm{a}$ & A & 44.25 & b & B & 55.13 & $\mathrm{a}$ & 99.75 & 126.37 \\
\hline San Andreas & 59.25 & $\mathrm{a}$ & A & 57.32 & $\mathrm{a}$ & A & 68.75 & a & A & 61.77 & $\mathrm{a}$ & 116.21 & 126.79 \\
\hline Albion & 58.87 & $\mathrm{a}$ & $\mathrm{A}$ & 67.00 & $\mathrm{a}$ & $\mathrm{A}$ & 69.50 & $\mathrm{a}$ & $\mathrm{A}$ & 65.12 & $\mathrm{a}$ & 120.96 & 133.00 \\
\hline Mean & 47.37 & & $\bar{B}$ & 43.86 & & $\mathrm{~B}$ & 65.92 & & $\overline{\mathrm{A}}$ & & & & \\
\hline & & & & & $\overline{\mathrm{ICF}}$ & $\mathrm{g} \mathrm{pla}$ & & & & & & $\left(\omega_{\mathrm{i}}\right)$ General & $\left(\omega_{i}\right)$ Favorable \\
\hline Cultivar & Lavras- & & & Guarapu & & & Uberlânc & & & Mean & & environment & environment \\
\hline Aromas & 701.75 & $\mathrm{~b}$ & A & 160.00 & $\mathrm{c}$ & B & 653.75 & $\mathrm{c}$ & $\mathrm{A}$ & 505.16 & $\mathrm{~d}$ & 58.55 & 81.77 \\
\hline Oso Grande & 872.00 & $\mathrm{a}$ & B & 232.65 & $\mathrm{c}$ & $\mathrm{C}$ & 1530.75 & a & A & 878.46 & b & 95.56 & 134.75 \\
\hline Dover & 744.25 & b & A & 494.43 & $\mathrm{~b}$ & B & 895.25 & b & A & 711.30 & $\mathrm{c}$ & 99.58 & 100.11 \\
\hline Sweet Charlie & 581.63 & $\mathrm{~b}$ & B & 225.00 & $\mathrm{c}$ & $\mathrm{C}$ & 888.75 & b & A & 565.12 & d & 67.23 & 85.09 \\
\hline Tudla & 547.25 & b & B & 386.68 & $\mathrm{~b}$ & B & 791.25 & b & A & 575.05 & d & 77.80 & 78.43 \\
\hline Festival & 715.88 & b & A & 516.00 & $\mathrm{~b}$ & A & 573.25 & $\mathrm{c}$ & A & 601.70 & d & 83.25 & 75.75 \\
\hline Camarosa & 1090.38 & $\mathrm{a}$ & B & 482.00 & $\mathrm{~b}$ & $\mathrm{C}$ & 1562.00 & a & A & 1044.79 & $\mathrm{a}$ & 129.28 & 155.74 \\
\hline Monterey & 633.13 & b & A & 643.00 & $\mathrm{a}$ & A & 818.25 & b & A & 698.12 & $\mathrm{c}$ & 96.39 & 87.21 \\
\hline Palomar & 646.25 & $\mathrm{~b}$ & A & 618.00 & $\mathrm{a}$ & A & 499.50 & $\mathrm{c}$ & A & 587.91 & d & 80.25 & 66.91 \\
\hline Portola & 596.63 & $\mathrm{~b}$ & A & 424.33 & $\mathrm{~b}$ & A & 616.50 & $\mathrm{c}$ & A & 545.81 & d & 77.01 & 74.49 \\
\hline Camino Real & 967.25 & $\mathrm{a}$ & A & 907.00 & $\mathrm{a}$ & A & 509.00 & $\mathrm{c}$ & B & 794.41 & $\mathrm{~b}$ & 106.21 & 80.59 \\
\hline San Andreas & 815.00 & $\mathrm{a}$ & A & 622.75 & $\mathrm{a}$ & A & 750.25 & b & A & 729.33 & $\mathrm{c}$ & 101.79 & 94.23 \\
\hline Albion & 1001.13 & $\mathrm{a}$ & A & 784.33 & $\mathrm{a}$ & A & 915.50 & b & A & 900.31 & $\mathrm{~b}$ & 125.46 & 115.25 \\
\hline Mean & 762.50 & & B & 499.70 & & C & 846.46 & & A & & & & \\
\hline
\end{tabular}

*Means followed by the same lower-case letter in the column and capital letter on the row are not significantly different by the Scott-Knott test at $\mathrm{P}<0.05$ probability.

Regarding NCF in Uberlândia (65.92), the performance was higher than in the environments of Lavras (47.37) and Guarapuava (43.86) (Table 2), matching with the Annicchiarico classification (1992), where Uberlândia, with an environmental index of 
13.53, was considered a favorable environment for this characteristic (Table 3). On the other hand, the environments Lavras (-5.01) and Guarapuava (-8.52) were considered unfavorable for NCF.

When we examined phenotypic stability, considering the general environment for NCF, cultivars Dover, Camarosa, Monterey, San Andreas and Albion stood out, and in the unfavorable environment, cultivars Dover, Monterey, Palomar, Portola, Camino Real, San Andreas and Albion were superior (Table 2). The number of commercial fruits characteristic is extremely important, taking into account that these are the fruits that suitable for in natura consumption and bring the highest prices.

Table 3. Number of fruits (TNF, plant ${ }^{-1}$ ) and total mass of fruits $\left(\mathrm{TMF}, \mathrm{g}\right.$ plant $\left.{ }^{-1}\right)$, number $\left(\mathrm{NCF}\right.$, plant $\left.{ }^{-1}\right)$ and mass of commercial fruits (MCF, g plant ${ }^{-1}$ ), classification and Annicchiarico environmental index of the environments.

\begin{tabular}{cccc}
\hline Environment & TNF plant $^{-1}$ & Classification & Environmental Index \\
\hline 1 & 90.00 & Unfavorable & -6.25 \\
2 & 94.71 & Unfavorable & -1.54 \\
3 & 104.05 & Favorable & 7.79 \\
\hline Environment & ${\text { TMF }\left(\mathrm{g} \mathrm{plant}^{-1}\right)}^{-1}$ & Classification & Environmental Index \\
\hline 1 & 956.80 & Favorable & 57.30 \\
3 & 722.88 & Unfavorable & -176.72 \\
\hline Environment & 1018.92 & Favorable & 119.41 \\
\hline 1 & NCF plant $^{-1}$ & Classification & Environmental Index \\
2 & 47.37 & Unfavorable & -5.01 \\
3 & 43.86 & Unfavorable & -8.52 \\
\hline Environment & 65.92 & Favorable & 13.53 \\
\hline 1 & MCF $\left(\mathrm{g} \mathrm{plant}^{-1}\right)$ & Classification & Environmental Index \\
\hline 3 & 762.50 & Favorable & 59.61 \\
\end{tabular}

*Environment ${ }^{1}$ Lavras-MG, ${ }^{2}$ Guarapuava-PR, ${ }^{3}$ Uberlândia-MG.

The mean of the MCF characteristic (846.46) in the Uberlândia environment was higher than that of Lavras (762.50) and Guarapuava (499.70) (Table 2). However, in the Annicchiarico classification, the environments located in Minas Gerais state were considered favorable, while the one in Guarapuava was considered unfavorable (Table 3).

Cultivars Oso Grande and Camarosa presented the highest production of commercial fruits in the environments Lavras and Uberlândia, and cultivars Camino Real, San Andreas and Albion stood out in the environments Lavras and Guarapuava. The diversity of production of fruits of the cultivars in relation to the environments observed

through a joint analysis is due to the action of the environmental elements and the cultivar $\mathrm{x}$ environment interaction, demonstrating how important it is to evaluate the phenotypic stability of strawberry cultivars.

One cultivar that, because of certain agronomic characteristics, is more suitable for growing in a region, may not present the same phenotypic behavior when exposed to soil and climate conditions in other growing environments, making it difficult to recommend a cultivar in a wide geographical area (Cruz et al. 2012). Along the same line, for phenotypic stability of MCF in a general environment, cultivars Camarosa, Camino Real, San Andreas and Albion are recommended, as they stood out with $\omega_{i}$ above $100 \%$. In the unfavorable environment, cultivars Oso Grande, Dover and Camarosa (Table 2) stood out. In other words, while cultivars Camarosa, Camino Real, San Andreas and Albion have greater genetic potential with higher stability for the production of commercial fruits in the 
environments evaluated, cultivars Oso Grande, Dover and Camarosa have the greatest potential in an environment in which the soil and climatic conditions are not as adequate.

The Camarosa cultivar presented the highest values for the MCF characteristic, which is considered the most relevant for strawberry producers, with values of 1090.38 (Lavras) and $1562.00 \mathrm{~g} \mathrm{plant}^{-1}$ (Uberlândia) (Table 2). Supporting these results observed for the Camarosa cultivar, Morales et al. (2012), assessing the productivity of strawberry cultivars in the Central-South region of Paraná, and Costa et al. (2015), selecting strawberry cultivars based on productivity, adaptability and stability in a low tunnel in Espírito Santo State, also observed good production when compared to other cultivars. According to the stability analysis through the Annicchiarico method (1992), cultivars Camarosa, San Andreas, Dover and Albion were the ones that stood out the most for the agronomic characteristics that we evaluated.

In the analysis of stability using the AMMI method, the accumulated explanation in the first axis was $80.21 \%, 92.04 \%, 86.11 \%$ and $93.94 \%$ for TNF, TMF, NCF and MCF, respectively, using $54.16 \%$ of the degrees of freedom that form the $\mathrm{C} \mathrm{x}$ E interaction (Table 1). The higher the explanation in the first axis, the higher the standard concentration, and the lower the concentration of noise in the AMMI analysis. In the biplot AMMI 1 model, axis $x$ represents TNF (Figure 2A), TMF (Figure 2B), NCF (Figure 2C) and MCF (Figure 2D); axis y represents the cultivar $\mathrm{x}$ environment interaction (PCAI 1). The strawberry cultivars and the environments that are closer to zero are the most stable ones, while the most distant ones from zero are the most adapted to specific environments and contribute the most to the cultivar $\mathrm{x}$ environment interaction (PCAI 1).

We found that Guarapuava and Uberlândia were the environments that contributed the most to the interaction (Figure 2A, 2B, 2C and 2D). On the other hand, the cultivars that contributed the most to the interaction were: for TNF (Dover and Festival); TMF (Oso Grande, Camarosa and Camino Real); NCF (Camino Real and Oso Grande) and MCF (Oso Grande, Camino Real and Camarosa), presenting the highest coordinates in the axis of PCAI 1. Despite the greatest contribution in the interaction, the ones that stood out for the yield above the general mean of the experiment were: for TNF (Dover); TMF (Oso Grande and Camarosa); NCF (Camino Real) and MCF (Oso Grande, Camino Real and Camarosa) (Figure 2).

According to the biplot analysis (Figure 2), taking into consideration the low scores (close to zero) typical of environments and cultivars that contribute little to the interaction, and characterized as stable, among the environments, Lavras was the most stable, while for cultivars, the ones that stood out were: for TNF (Monterey, San Andreas and Portola), TMF (Albion and Portola), NCF (San Andreas, Monterey and Festival) and MCF (Dover and Tudla). Regarding the greatest phenotypic stability and yield above the general mean of the experiment, for TNF (San Andreas); TMF (Albion); NCF (San Andreas and Monterey); and MCF (Dover) stood out.

When we compared stability for a specific environment in the AMMI analysis, in Guarapuava, cultivar Festival stood out for TNF, and in Lavras, cultivars Oso Grande, Sweet Charlie, Tudla, Portola and Albion (Figure 2A); for TMF in Uberlândia, cultivar Oso Grande (Figure 2B); for NCF in Lavras, Tudla, Festival and Portola, while in Uberlândia, the Dover cultivar (Figure 2C); and for MCF in Uberlândia, cultivar Oso Grande, and in Lavras cultivars Dover, San Andreas and Monterey (Figure 2D). 

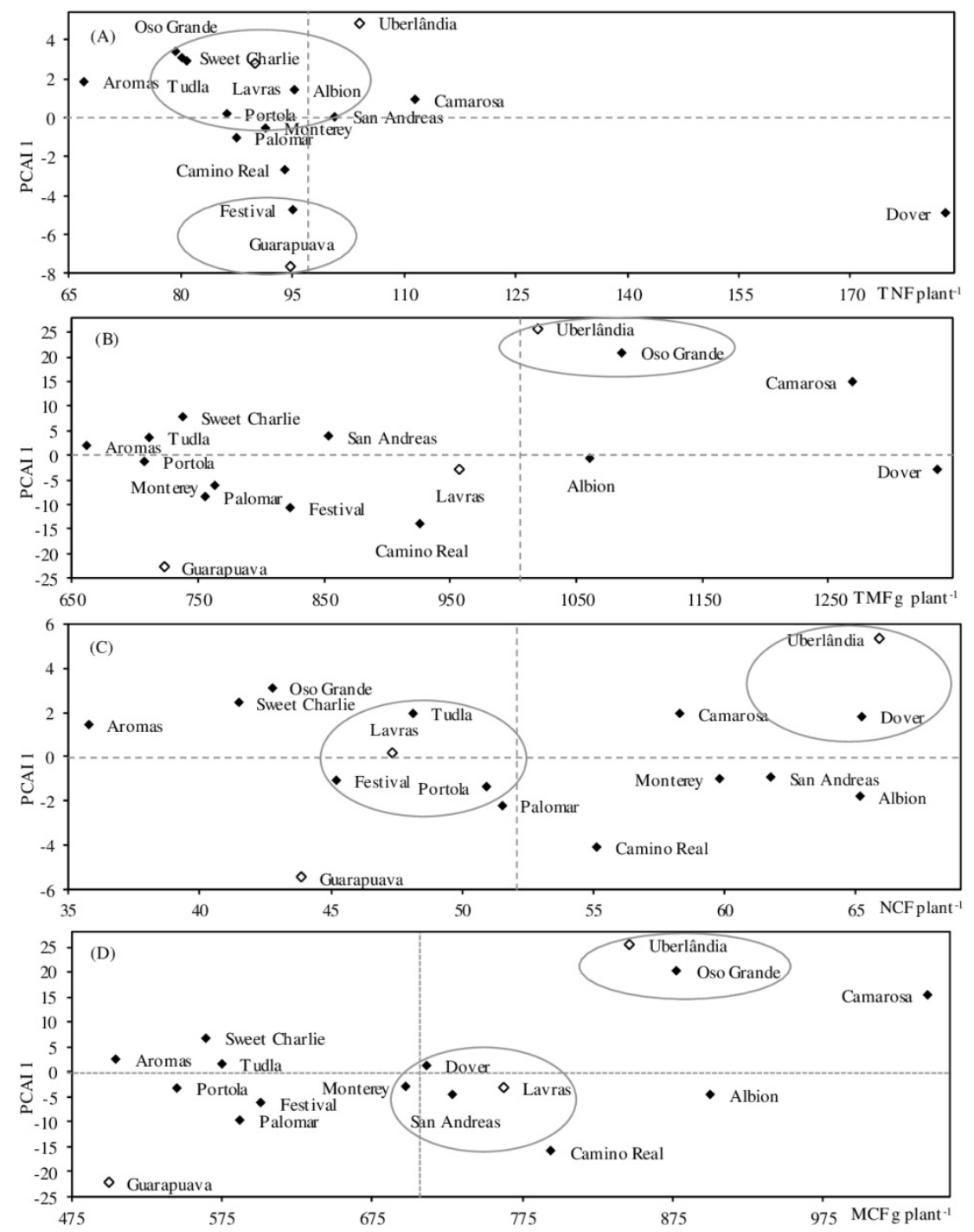

Figure 2. AMMI 1 biplot analysis with the first main axis of interaction (PCAI 1) for the total number of fruits (A), total mass of fruits (B), number of commercial fruits (C) and mass of commercial fruits (D) of 13 strawberry cultivars evaluated in Lavras-MG, Guarapuava-PR and Uberlândia-MG.

The stability evaluation methods (Annicchiarico and AMMI) identified different strawberry cultivars as the most stable. A coincidence was noticed between the methods only for Albion, regarding TMF, and Monterey and San Andreas for NCF. In wheat, a divergence of stability of genotypes using the Annicchiarico and AMMI methods (Possatto Júnior et al. 2017b) was also noticed. Also, it is reported that the Eberhart and Russell, AMMI methodologies, and mixed models can also present similar results in the classification of genotypes with broad stability (Faria et al. 2017). Nonetheless, these same 
authors noticed divergence in the indication of maize hybrids with specific adaptability to favorable and unfavorable environments.

The Annicchiarico and AMMI methods used together provide relevant information to farmers when choosing a strawberry cultivar. The use of several methods is recommended to evaluate the phenotypic stability and help in the decision-making process (Polizel et al. 2013).

\section{CONCLUSIONS}

The cultivar that stood out for its agronomic performance for the total number of fruits, total mass of fruits and number of commercial fruits was Dover, while for mass of commercial fruits it was the Camarosa cultivar, even though they were affected by the genotype $\mathrm{x}$ environment interaction. Regarding phenotypic stability and yield in different growing environments, strawberry cultivar Albion stood out for the total mass of fruits, and Monterey and San Andreas for the number of commercial fruits.

\section{CONFLICTS OF INTEREST}

The authors declare no conflict of interest.

\section{REFERENCES}

Annicchiarico P (1992). Cultivar adaption and recomendation from alfalfa trials in Northern Italy. J. Genet. Breed. 46: 269-278.

Barros HB, Sediyama T, Melo AV, Fidelis RR, et al. (2012). Adaptabilidade e estabilidade de genótipos de soja por meio de métodos uni e multivariado. J. Biotec. Biodivers. 3: 49-58.

Bornhofen E, Benin G, Storck L, Woyan LG, et al. (2017). Métodos estatísticos para estudo de adaptabilidade e estabilidade em trigo. Bragantia. 76: 1-10. http://dx.doi.org/10.1590/1678-4499.557

Carvalho ADF, Silva GO, Resende FV, (2017). Adaptabilidade e estabilidade de populações de cenoura pelo método REML/BLUP. Hortic. Bras. 35: 69-74. http://dx.doi.org/10.1590/s0102-053620170111

Costa AF, Leal NR, Ventura JA, Gonçalves LSA, et al. (2015). Adaptability and stability of strawberry cultivars using a mixed model. Acta Scient. Agron. 37: 435-440. http://dx.doi.org/10.4025/actasciagron.v37i4.18251

Costa AF, Teodoro PE, Bhering LL, Leal NR, et al. (2016). Biplot analysis of strawberry genotypes recommended for the State of Espírito Santo. Genet. Mol. Res. 15: 1-9. http://dx.doi.org/10.4238/gmr.15038919

Cruz CD, Carneiro PCS, Regazzi AJ. (2014). Modelos biométricos aplicados ao melhoramento genético. 3. ed. rev. ampl. Viçosa: UFV.

Cruz CD (2013). GENES - a softaware package for analysis in experimental statistics and quantitative genetics. Acta Scient. Agron. 35: 271-276. http://dx.doi.org/10.4025/actasciagron.v35i3.21251

Cruz CD, Regazzi AJ, Carneiro PCS. (2012). Modelos biométricos aplicados ao melhoramento genético. v.1. 4.ed. Viçosa, MG. UFV.

Empresa Brasileira de Pesquisa Agropecuária - EMBRAPA. (2013). Sistema brasileiro de classificação de solos. 3.ed. Brasília, 353p.

Faria SV, Luz LS, Rodrigues MC, Carneiro JES, et al. (2017). Adaptability and stability in commercial maize hybrids in the southeast of the State of Minas Gerais, Brazil. Rev. Ciênc. Agron. 48: 347-357. http://dx.doi.org/10.5935/1806-6690.20170040

Ferreira DF (2000). Sistemas de análises estatística 3.1. Lavras: FAEPE/UFLA/PEX.

Galvão AG, Resende LV, Maluf WR, Resende JTV, et al. (2017). Breeding new improved clones for strawberry production in Brazil. Acta Scient. Agron. 39: 149-155. http://dx.doi.org/10.4025/actasciagron.v39i2.30773

García-Peña M, Dias CTS. (2009). Análise dos modelos aditivos com interação multiplicativa (AMMI) bivariados. Rev. Bras. Biome. 27: 586-602.

Lima LHS, Braccini AL, Scapim CA, Piccinin GG, et al. (2017). Adaptability and stability of canola hybrids in different sowing dates. Rev. Ciênc. Agron. 48: 374-380. http://dx.doi.org/10.5935/1806-6690.20170043 
Morais LK, Santiago AD, Cavalcante MHB. (2017). Phenotypic stability in cassava estimated by the AMMI analysis with supplementary genotypes. Crop Breed. Appl. Biot. 17: 366-372. http://dx.doi.org/10.1590/1984-70332017v17n4a55

Morales RGF, Faria MV, Resende JTV, Rissini ALL, et al. (2012). Produtividade de morangueiro em função da adubação orgânica complementar em cultivo protegido. Ambiência. 8: 23-33. http://dx.doi.org/10.5777/ambiencia.2012.01.02

Oliveira AES, Santos CAF, Luz LN, Oliveira VR, et al. (2016). Adaptability and stability of 'Valenciana' onion populations in the Brazilian tropical semiarid. Aust. J. Crop Scien. 10: 1182-1187. http://dx.doi.org/10.21475/ajcs.2016.10.08.p7890

Pereira WR, Souza RJ, Yuri J, Ferreira S. (2013). Produtividade de cultivares de morangueiro, submetidas a diferentes épocas de plantio. Hortic. Bras. 31: 500-503.

Pimenta S, Menezes D, Neder DG, Melo RA, et al. (2016). Adaptability and stability of pepper hybrids under conventional and organic production systems. Hortic. Bras. 34: 168-174. http://dx.doi.org/10.1590/S0102053620160000200004

Polizel AC, Juliatti FC, Hamawaki OT, Hamawaki RL, et al. (2013). Adaptabilidade e estabilidade fenotípica de genótipos de soja no estado do Mato Grosso. Biosc. J. 29: 910-920.

Possatto Junior O, Faria MV, Battistelli GM, Rossi ES, et al. (2017a). Avaliação de linhagens $\mathrm{S}_{2}$ de milho em topcrosses com linhagem-elite testadora. Rev. Bras. Milho Sorgo. 16: 259-271. http://dx.doi.org/10.18512/1980-6477/rbms.v16n2p297-309

Possatto Junior O, Faria MV, Mendes MC, Oliboni R, et al. (2017b). Adaptability and stability of wheat genotypes on ten environments in the states of Paraná and São Paulo, Brazil. Agrária. 12: 113-121. http://dx.doi.org/10.5039/agraria.v12i2a5426

Ramos LM, Sanches A, Cotes JM, Cargnelutti Filho A. (2011). Adaptabilidade e estabilidade do rendimento de genótipos de arroz, mediante duas metodologias de avaliação na Colômbia. Acta Agron. 60: 39-49.

Rosa HT, Streck NA, Walter LC, Andriolo JL, et al. (2013). Crescimento vegetativo e produtivo de duas cultivares de morango sob épocas de plantio em ambiente subtropical. Rev. Ciênc. Agron. 44: 604-613.

Santos JO, Rodrigues R, Leal NR, Sudré CP, et al. (2015). Estabilidade fenotípica em abóbora. Hortic. Bras. 33: 498-503. http://dx.doi.org/10.1590/S0102-053620150000400015

Schmildt ER, Nascimento AL, Cruz CD, Oliveira JAR. (2011). Avaliação de metodologias de adaptabilidade e estabilidade de cultivares milho. Acta Scient. Agron. 33: 51-58. http://dx.doi.org/10.4025/actasciagron.v33i1.5817

Silva CA, Faria MV, Rossi ES, Possatto Junior O, et al. (2017). Performance and stability of maize topcross hybrids from partly inbred lines. Semina: Ciênc. Agrária. 38: 2899-2908. http://dx.doi.org/10.5433/1679$\underline{0359.2017 \mathrm{v} 38 \mathrm{n} 5 \mathrm{p} 2899}$

Trani PE, Tivelli SW, Carrijo OA. (2011). Fertirrigação em hortaliças. 2. ed.rev.atual. Campinas: Instituto Agronômico.

Zobel RW, Wright AJ, Gauch HG. (1988). Statistical analysis of a yield trial. Agron. J. 80: 388-393. http://dx.doi.org/10.2134/agronj1988.00021962008000030002x 